\section{Visitors to Britain}

The British Council seems to be pleased with the way its scheme for awarding scholarships for advanced study has been building up. In the present academic year, 126 scientists from various places are studying in Britain, most of them for periods of one academic year or more. Since 1963, the numbers of scholarships awarded to scientists have increased by roughly 50 per cent. At present, the pure sciences and technology account for 49 and 50 scholarship holders respectively. There is a steady trickle of half a dozen or so each year of people anxious to have first-hand experience of school science teaching in Britain. Most of the visitors to Britain under the scheme come from European countries-in the past four years there has been an especially rapid growth of business with Czechoslovakia, Hungary, Romania and Bulgaria, and 32 scientists from these countries are now in Britain under the scheme. 39 scientists have come from elsewhere in Europe and the scientists now account for more than a quarter-or, if awards to doctors are also included, more than 40 per cent-of the scholarships awarded by the British Council each year.

The ideal British Council scholar is a man or woman between 25 and 35 . Although the awards cover cost of travel, tuition and maintenance, one snag may be that they are not always generous enough to keep all applicants in styles to which some of them may have become accustomed. Another difficulty, no doubt inescapable in arrangements of this kind, is that applications must be made roughly a year before the beginning of an academic year.

\section{New Chairman for CEI}

Mr Leonard Ducquer is the new Chairman of the Council of Engineering Institutions. He was elected on July 13 to the post left vacant by the death of Mr H. N. Pemberton on April 6, 1967. Mr Ducquer, 65 , now takes office for a period of 18 months.

Mr Ducquer was educated at Haberdashers Aske's and the London Polytechnic Engineering College, and began his career with the British Thomson Houston Company in 1920. Until 1938 he worked in outside construction and contract engineering, and then moved to selling switchgear. BTH is one of the roots from which Associated Electrical Industries Ltd sprang, and from 1958 to $1965 \mathrm{Mr}$ Ducquer was divisional director and general manager of the Heavy Plant Division of AEI. Since 1965, he has been a group consultant to AEI and a member of the board of AEI Automation. Mr Ducquer has been a member of the Council of Engineering Institutions for some years, and already has experience of its internal operations; he has been chairman of the overseas relations subcommittee and the finance sub-committee.

\section{Women Engineers}

WoMEN feel that they are an underprivileged class, at least where engineering is concerned. This is what emerged from the last day of the Second International Conference of Women Scientists and Engineers, held last week in Cambridge. Delegates felt that the difficulty lay in attracting girls into engineering, as there are always places for the determined few who wish to make it their career. The unfortunate view of engineering as a profession for those who like to get oil under their nails gives it a particularly unfeminine image, while very few schools are prepared to encourage their girls to do practical rather than academic science. Several speakers described how they met not only with discrimination in employment (a survey in Canada revealed that women engineers are better qualified than men in equivalent jobs) but also with some social hostility from their contemporaries, both male and female. Mrs Josephine Webb produced some interesting figures to show how strong these pressures are.

Table 1. estrmated RATio OF MEN TO WOMEN ENGINEERS IN VARIOUS COONTRIES

Ratio of men engineers to women engineers

USSR
Philippines
France
Sweden
USA
Britain
Japan
India
Canada
Republic of South Africa

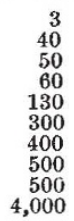

There seems to be less prejudice against women as engineers in some developing countries than elsewhere. Delegates described how in India and the Philippines, women engineers can command well paid responsible jobs and become respected members of society. In Nigeria, however, the attitude of men towards women engineers is just as bad as in the West. One reason suggested for the "backward" attitude of the West was that the position of a woman as a mother is more highly regarded than her position as a technologist.

Most delegates agreed that the way to improve the situation is through education. Because most women who graduate in engineering go into industry, there is a shortage of teachers of technical subjects, and this does not encourage a more liberal attitude in the schools towards engineering as a career for girls. In future perhaps women engineers who cannot work full time because of their family commitments will be able to go into teaching part time, but this is by no means the whole solution to the problem. A delegate from Nigeria pointed out that one of the few positive things many women engineers can do is to have daughters, and bring them up with a different attitude to technology.

\section{End of an Era?}

THE UK Atomic Energy Authority has been saying goodbye to Sir John Cockcroft, the first director of the Atomic Energy Research Establishment at Harwell and a member of the UK Atomic Energy Authority since its formation out of the atomic energy research group at the Ministry of Supply in August 1954. Sir John has been Master of Churchill College, Cambridge, since 1959, and a part-time member of the board of the AEA since that time. Although Sir John does not retire officially until the end of this month, his colleagues on the AEA found his last appearance at a board meeting on July 6 something of a wrench.

Within the AEA, Sir John is most affectionately regarded for the intellectual stature which he gave to the Harwell establishment from its beginning 